\title{
Population Structure of Potebniamyces pyri in the U.S. Pacific Northwest and Evidence of Outcrossing Inferred with Sequence-Characterized Amplified Region Markers
}

\author{
Q. Liu, T. L. Peever, and C. L. Xiao
}

First and third authors: Department of Plant Pathology, Washington State University, Tree Fruit Research and Extension Center, 1100 North Western Avenue, Wenatchee 98801; and second author: Department of Plant Pathology, Washington State University, Pullman 991646430.

Accepted for publication 8 January 2009.

\begin{abstract}
Liu, Q., Peever, T. L., and Xiao, C. L. 2009. Population structure of Potebniamyces pyri in the U.S. Pacific Northwest and evidence of outcrossing inferred with sequence-characterized amplified region markers. Phytopathology 99:532-539.

Potebniamyces pyri is the cause of Phacidiopycnis rot of d'Anjou pear, which is grown primarily in Washington and Oregon. To estimate the population structure of $P$. pyri, 146 single-spore isolates were sampled from five major pear-production areas and scored for variation at eight sequence-characterized amplified region (SCAR) loci. Significant genetic differentiation was detected among five subpopulations and a total of 54 multilocus genotypes were identified, with significant genotypic diversity in each subpopulation. No genotype was shared among more than three subpopulations. To estimate the relationship between phenotype and
\end{abstract}

ABSTRACT multilocus SCAR genotype, four to five representative isolates of each dominant SCAR genotype in each subpopulation were assayed for growth rate on oatmeal agar and virulence on d'Anjou pear fruit. Significant differences in daily growth rates and virulence were detected among genotypes; however, genotype was not predictive of virulence. To assess the mating system of the pathogen, 10 ascospores were sampled from each of 20 apothecia from a commercial orchard and scored for five SCAR markers. Segregation of alleles at one or more SCAR loci was detected among 18 of 20 ascospore progeny sets, indicating that $P$. pyri is likely a heterothallic fungus with a predominantly outcrossing mating system.

Additional keywords: Phacidiopycnis piri, postharvest disease, Pyrus communis.
Winter pear (Pyrus communis L.) in the United States is produced primarily in the Pacific Northwest (PNW), including the Omak, Wenatchee, and Yakima areas of central Washington and the Hood River and Medford areas of Oregon. d'Anjou is the major winter pear cultivar grown in this region. The Wenatchee River Valley and the Hood River area are the two primary districts for d'Anjou pear production and account for $\approx 80 \%$ of the d'Anjou pear production in the nation (22).

Phacidiopycnis rot, caused by Potebniamyces pyri (Berk. \& Broome) Dennis (anamorph Phacidiopycnis piri (Fuckel) Weindlm.) (10), is a recently recognized postharvest disease in d'Anjou pear in the United States $(57,59)$. This disease has been previously recorded in Europe and India $(49,52)$. In Washington State, Phacidiopycnis rot is an important postharvest disease of d'Anjou pear, accounting for $\approx 30 \%$ of the total decay on packed d'Anjou pear (59).

The inoperculate discomycete, Potebniamyces pyri, was originally described under the name Phacidiella discolor by Potebnia (46). The fungus can cause bark necrosis and branch cankers of apple (Malus $\times$ domestica Borkh.) and pear trees $(3,4,13$, $46,54,60)$. In the PNW, pycnidia are considered to be the main source of inoculum responsible for fruit infection, and viable pycnidia and conidia can be detected on dead bark and spurs of

Corresponding author: C. L. Xiao; E-mail address: clxiao@wsu.edu

* The $\boldsymbol{e}$-Xtra logo stands for "electronic extra" and indicates that the online version contains a table showing isolates of Potebniamyces pyri sampled from five d'Anjou pear-production areas in Oregon and Washington.

doi:10.1094/PHYTO-99-5-0532

(C) 2009 The American Phytopathological Society pear trees throughout the pear-fruit growing season $(58,60)$. Apothecia have been observed infrequently in the Wenatchee, Hood River, and Medford areas (60), suggesting that ascospores may be important in the life cycle of the fungus. Both conidia and ascospores are water dispersed (10) and the optimum temperature for conidial germination and mycelial growth is $\approx 20^{\circ} \mathrm{C}(28,61)$.

Because Potebniamyces pyri is a recently recognized pathogen on pear in the U.S. PNW, neither its origin nor the relationships among fungal populations in different pear-production areas are known. Knowledge of the population genetic structure is key to understanding the evolutionary history of a fungal pathogen, its potential to evolve, and, ultimately, to develop effective control strategies $(34,36,39)$. Various molecular markers, such as random amplified polymorphism DNA (RAPD), restriction fragment length polymorphism (RFLP), amplified fragment length polymorphism (AFLP), and sequence-characterized amplified region (SCAR), have been used to estimate the population structures of plant-pathogenic fungi (32). SCAR markers maintain many of the advantages of RAPD such as ease of implementation, amplification from small amounts of genomic DNA, and the ability to screen a large number of isolates in a short time. They also address some of the shortcomings of RAPD such as reproducibility $(32,42)$ and homoplasy $(48)$. SCAR markers can be either dominant or co-dominant $(8,42)$. When SCAR segregates as dominant markers, differentiating null alleles and lack of amplification due to failure of the polymerase chain reaction (PCR) can be problematic. Inclusion of an internal amplification control (IAC) in the PCR can address this problem (18). SCAR markers have typically been derived from RAPD $(9,19,24,31,42,53)$ or AFLP (47) and have been used to map resistance genes $(9,42,47)$ 
and for pathogen detection $(19,24)$. To date, the use of SCAR markers in studies of fungal population structure has been limited $(31,53)$.

One potential application of putatively neutral genetic markers is to attempt to correlate multilocus genotype (MLG) to one or more biologically interesting phenotypes such as fungicide resistance $(2,15,17,29)$, host specificity $(44)$, or virulence $(2,6,14,50)$. Such correlations are generally found only for pathogens with selfing or asexual mating systems $(15,17,29,50)$, because the occurrence of recombination is expected to break down associations between molecular genotypes and phenotypic traits $(2,6,14$, $36,41,43)$.

In addition to their application to the study of the genetic structure of fungal pathogen populations, molecular markers have also been used to infer the reproductive mode of fungi $(2,12$, 20,37). Although apothecia of $P$. pyri have been infrequently observed in pear orchards in the PNW, attempts to perform in vitro laboratory crosses have not been successful (Q. Liu and C. L. Xiao, unpublished). To date, there is no information available on the mating system of $P$. pyri. Development of a set of polymorphic molecular markers for PNW populations of this fungus will allow us to analyze the population structure and assess reproductive mode of $P$. pyri in the field (37).

The objectives of this study were to (i) develop a set of molecular markers for $P$. pyri based on SCARs and use them to analyze the population structure of the fungus in five pearproduction areas in the PNW, (ii) determine whether virulence of the fungus on d'Anjou pear fruit can be predicted from multilocus SCAR genotype, and (iii) use SCAR markers to characterize the mating system of $P$. pyri in a natural population.

\section{MATERIALS AND METHODS}

Sources of isolates and fungal culture. Isolates of $P$. pyri were collected from five d'Anjou pear-production areas in the PNW, including Omak, Wenatchee, and Yakima in Washington and Hood River and Medford in Oregon. For the purposes of this study, samples from these areas will be referred to as subpopulations. Mass-hyphal isolates were obtained from decayed d'Anjou fruit collected from packing houses following the procedure of Xiao and Boal (59) or from bark samples collected during an orchard survey for $P$. pyri (60). To obtain singleconidial isolates, pycnidia were produced on oatmeal agar (OA) (60 $\mathrm{g}$ of iron- and zinc-fortified single-grain oatmeal [Gerber, Fremont, MI], $15 \mathrm{~g}$ of agar, and 1 liter deionized water, sterilized for $90 \mathrm{~min}$ ) following the protocol of Xiao and Sitton (61). A single pycnidium from a 10 - to 12 -week-old OA culture was crushed on a glass slide in a drop of sterile water. The presence of conidia was determined with a compound microscope. A drop of diluted conidial solution was streaked with a $10-\mu$ polystyrene sterile disposable inoculation loop on acidified potato dextrose agar (APDA) $(4.0 \mathrm{ml}$ of a $25 \%$ solution of lactic acid per liter of medium) (Difco Laboratories, Detroit). The identity of singleconidial colonies was confirmed by microscopy and each colony was transferred to OA. The remainder of the single-spore isolates was obtained directly from pycnidia or apothecia on dead bark samples collected in pear orchards (60) with assistance of a dissecting microscope following the procedure described above. In total, 146 single-spore isolates were obtained and used to estimate population structure in this study. All isolates are maintained at the Tree Fruit Research and Extension Center, Washington State University, Wenatchee.

Mycelial plugs of OA cultures were stored in sterile water at $4{ }^{\circ} \mathrm{C}$ for short-term storage ( $<6$ months) and in $15 \%$ sterile glycerol at $-80^{\circ} \mathrm{C}$ for long-term storage. To reactivate cultures, pieces of mycelial plugs were removed from stock cultures and grown on $\mathrm{OA}$ for 5 days at $20^{\circ} \mathrm{C}$ in the dark. Mycelial plugs ( $4 \mathrm{~mm}$ in diameter) were cut from the margin of actively growing colonies and used as inoculum for OA. For slow-growing isolates, incubation periods were extended in order to provide enough mycelial plugs for subsequent experiments.

Production of mycelium and extraction of DNA. Isolates were grown in 60-mm-diameter plastic petri plates, each containing $10 \mathrm{ml}$ of sterilized nutrient solution $(200 \mathrm{ml}$ of freshly made pear juice and $2 \mathrm{~g}$ of yeast extract [Difco, Sparks, MD] per liter). Plates were incubated for 7 to 10 days at $20^{\circ} \mathrm{C}$ in the dark without shaking until the surface was fully colonized by mycelium. Mycelium was harvested by removing mycelial mats with a sterile disposable inoculation loop. Harvested mycelium was stored in Falcon 14-ml polypropylene round-bottom tubes (Becton Dickinson and Company, Franklin Lakes, NJ) at $-20^{\circ} \mathrm{C}$, lyophilized, and ground to fine powder in the same tubes with a pestle. DNA was extracted according to the method of Lee and Taylor (25) with modification of the lysis buffer to include $100 \mathrm{mM}$ Tris (pH 8.0) rather than $50 \mathrm{mM}$ Tris $(\mathrm{pH} \mathrm{7.2)}$ and omit 2 -mercaptoethoanol. RNA was digested with Rnase at $10 \mathrm{mg} / \mu \mathrm{l}$ (Promega Corp., Madison, WI) at $37^{\circ} \mathrm{C}$ for $2 \mathrm{~h}$ and DNA samples were quantified in $1 \%$ agarose gel with known concentration of undigested lambda DNA (Promega Corp.). Template genomic DNA was diluted to 5 to $10 \mathrm{ng} / \mu \mathrm{l}$ before use in PCR amplifications.

Development of SCAR markers. Two sets of commercial 10mer primers (kits A and B; Operon Technologies, Alameda, CA) were screened in RAPD-PCR against 13 P. pyri isolates randomly selected from various orchards in the Wenatchee and Hood River subpopulations. Polymorphic bands were purified from agarose gels using Qiagen Gel Extraction columns (Qiagen Inc., Valencia, CA) according to the manufacturer's instructions. Amplicons were reamplified with the original 10-mers under the same PCR conditions, purified through QIAquick PCR purification columns (Qiagen Inc.) according to the manufacturer's instructions, and cloned into the pCR4-TOPO vector using the TOPO TA Cloning Kit (Invitrogen, Carlsbad, CA). Plasmid DNAs were isolated with the QIAprep Spin Miniprep Kit (Qiagen Inc.) and inserts were analyzed by digesting the plasmid DNA with EcoRI (New England Biolabs Inc., Beverly, MA). Clones possessing inserts of size equivalent to the original PCR product from each RAPD primer were sequenced on both strands with each sequence reaction containing 0.5 to $1 \mu \mathrm{g}$ DNA, 3.2 pmol primer, $4 \mu \mathrm{l}$ of BigDye Terminator Cycle Sequencing Ready Reaction Mix (Applied Biosystems, Foster City, CA), and sterile distilled water in 10- $\mu$ l total volumes. Cycling conditions for the cycle sequencing consisted of 25 cycles of $15 \mathrm{~s}$ at $96^{\circ} \mathrm{C}, 15 \mathrm{~s}$ at $50^{\circ} \mathrm{C}$, and $4 \mathrm{~min}$ at $60^{\circ} \mathrm{C}$. Products were purified using Centriflex Gel Filtration Cartridges (Edge Biosystems, Gaithersburg, MD) and dried in a rotary evaporator, and sequences were read in the Laboratory for Biotechnology and Bioanalysis, School of Molecular Biosciences, Washington State University, Pullman.

Cloned sequences trimmed of vector sequence were BLASTed against GenBank nucleotide sequence databases and conceptually translated in all six frames and BLASTed against GenBank protein sequence databases. No similarities to any known or predicted genes were found. Specific primers were designed to amplify each cloned sequence using the primer design program Primer3 (http://fokker.wi.mit.edu). Each primer set (Operon Technologies) was then used to amplify products from a set of $P$. pyri isolates possessing different RAPD-PCR fingerprints to screen for polymorphisms. Amplicons were purified through QIAquick PCR purification columns (Qiagen Inc.) and sequenced on both strands as described above. Sequences were aligned in Clustal X 1.83 (55) and polymorphic sites were evaluated for their potential in the design of allele-specific primers, including the number and type of mismatches and physical distance to the $3^{\prime}$ end of the primer $(23,51)$. Allele-specific primers were designed manually by placing the mismatches as close as possible to their $3^{\prime}$ end. Thus, a candidate SCAR primer set was assembled by combining 
an allele-specific primer with a corresponding specific primer for each locus.

Each candidate SCAR primer set was screened against the same set of genetically variable isolates mentioned above in a multiplex PCR, which included a primer set to amplify nucleotides 728 to 986 of translation elongation factor $1 \alpha$ (EF-1 $\alpha)(45)$. EF-1 $\alpha$ served as an IAC, allowing the differentiation of null alleles from lack of PCR amplification. In all, eight SCAR primer sets which revealed polymorphism among the screening isolates were identified, and these primers were applied in the population study.

All SCAR marker amplifications were conducted in a MyCycler thermal cycler (Bio-Rad Life Science Research Group, Hercules, $\mathrm{CA}$ ) in final reaction volumes of $20 \mu \mathrm{l}$. Concentrations of reagents were $1 \times$ buffer containing $2 \mathrm{mM} \mathrm{MgCl} 2$ and loading dye (Idaho Technologies, Salt Lake City, UT), 2 units of Taq DNA polymerase (New England Biolabs), $0.2 \mathrm{mM}$ dNTPs (New England Biolabs), $0.4 \mu \mathrm{M}$ of each primer (SCAR and EF-1 $\alpha$ ), and 5 to $10 \mathrm{ng}$ of genomic DNA. Cycling conditions consisted of: $95^{\circ} \mathrm{C}$ (1 min), 1 cycle; $94^{\circ} \mathrm{C}(30 \mathrm{~s})$, variable annealing temperatures depending on the primer set $(30 \mathrm{~s}), 72^{\circ} \mathrm{C}(1 \mathrm{~min}), 35$ cycles; and $72^{\circ} \mathrm{C}(10 \mathrm{~min}), 1$ cycle. Each PCR $(18 \mu \mathrm{l})$ was loaded onto $1 \%$ agarose gels stained with ethidium bromide at $0.5 \mu \mathrm{g} / \mathrm{ml}$. Amplicons were visualized using a digital imaging system (Ultra Violet Products, Upland, CA) after electrophoresis in $1 \times$ Tris-borate EDTA buffer.

Marker scoring and data analysis. The presence of a target band amplified from a given isolate was scored as "1" and absence of a target band (null allele) was scored as " 0 ". Data were recorded for a given PCR only when the amplification of the EF$1 \alpha$ IAC was positive (Fig. 1). All null alleles (lack of amplicon) with negative IAC were repeated until a positive amplification was obtained with the IAC. If no IAC amplification product was obtained, data were recorded as missing. Allele frequencies within each subpopulation and Nei's genetic distances (40) between pairs of subpopulations were estimated using POPGENE (v. 3.2; Molecular Biology and Biotechnology Centre, University of Alberta, Edmonton, Canada). Heterogeneity in allele frequencies among subpopulations was tested using the likelihood ratio $\chi^{2}$ statistic $\left(G^{2}\right)$ in POPGENE (5). Pairwise comparisons of $\theta$ (the estimate of degree of gene differentiation between subpopulations) (56) and genotypic diversity were performed using MultiLocus v.1.3 (1). Significance of the differentiation statistics were tested using 1,000 randomly permuted data sets in Multilocus. Genotypic richness in each subpopulation was assessed directly as the number of genotypes in each subpopulation as sample sizes were approximately equal ( $n=27$ to 32$)$ among subpopulations (16). To correct for potential bias associated with resampling the same MLGs, a clone-corrected data set was constructed for each subpopulation by selecting one clone (isolate) per genotype. Allele frequencies, $G^{2}$, Nei's genetic distances, and $\theta$ values were reestimated with clone-corrected data sets as described above.

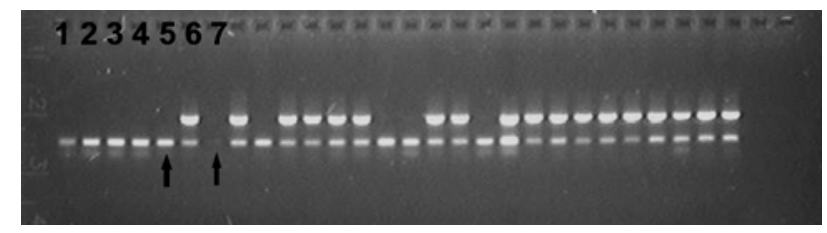

Fig. 1. Amplification of sequence-characterized amplified region locus B5-41L/NR1 among 28 isolates of Potebniamyces pyri from the Yakima subpopulation. Multiplex polymerase chain reaction included an EF-1 $\alpha$ primer pair as an internal amplification control (IAC). Upper bands are B5-4-1L/NR1 amplicons and lower bands are EF-1 $\alpha$ amplicons. A null allele for B5-41L/NR1 can be seen in lane 5 (no B5-4-11/NR1 amplicon but IAC amplicon) while the result in lane 7 needed further confirmation (no B5-4-1L/NR1 amplicon, no IAC amplicon).
Selection of isolates for growth rate and virulence test. Multilocus SCAR genotypes that occurred in frequencies $>20 \%$ in any subpopulation or the genotype with highest frequency in each subpopulation were selected for comparison of growth rates. Growth rates and virulence of four to five representative isolates of each genotype were measured on OA and d'Anjou pear fruit. Additionally, three isolates with identical genotypes were selected from each of the two orchards in the Omak and Wenatchee subpopulations to determine whether geographic origin of the isolate had an effect on daily growth rate or virulence level.

Growth rate on OA. OA plates were inoculated with mycelial plugs ( $4 \mathrm{~mm}$ in diameter) and incubated at 0 and $20^{\circ} \mathrm{C}$ in the dark. The experiment was arranged in a complete randomized design with three replications. Colony diameters were recorded at 4 and 6 days postinoculation at $20^{\circ} \mathrm{C}$ and 10 and 20 days postinoculation at $0^{\circ} \mathrm{C}$. For slow-growing isolates, colony diameters were recorded when they were measurable. Plates were recorded for each isolate for each measurement. Daily growth rate of each isolate was calculated by dividing the radius of the colony by the number of days since inoculation. This experiment was performed twice for each temperature.

Virulence on d'Anjou pear fruit. d'Anjou pear fruit were harvested in early September. Fruit were surface-disinfested in $0.5 \% \mathrm{NaOCl}$ for $5 \mathrm{~min}$, washed with running water, and air dried. An artificial wound was made on each fruit with a sterile 4-mmdiameter finishing nail head to a depth of $4 \mathrm{~mm}$. Each wound was inoculated with a 4-mm-diameter mycelial plug that was cut from the margin of a 5-day-old culture on OA, with the mycelial side facing down. Each wound was covered with a piece of moistened sterile cheesecloth $\left(2\right.$ by $\left.2 \mathrm{~cm}^{2}\right)$. In all, 20 fruit were inoculated with each isolate and 20 wounded fruit were mock inoculated with sterile, distilled water as controls. Inoculated fruit were placed on a fiberboard fruit tray, transferred into a cardboard box, and covered with aluminum foil. Two trays were placed in each box lined with perforated polyethylene bags. All inoculated fruit were incubated at $0^{\circ} \mathrm{C}$ in air (commercially, pear fruit are commonly stored at $\approx 0^{\circ} \mathrm{C}$ ). Lesion diameter (decayed area) on each fruit was recorded 8 weeks after inoculation and was used to indicate the virulence of each isolate. This experiment was repeated once.

Statistical analysis. Homogeneity of variances between the two independent virulence experiments was tested by comparing the $F$ values with PROC TTEST in SAS (version 9.1; SAS Institute, Cary, NC). Data from two runs of each experiment were pooled for analysis for daily growth rate and virulence of each isolate when the variances between two runs were homogenous. Otherwise, data of each run were presented separately. One-way analysis of variance was conducted with SAS PROC GLM to determine whether there were differences in daily growth rate and virulence among genotypes. Means were separated using the Waller-Duncan K-ratio $t$ test at $\mathrm{K}$ ratio $=100(P=0.05)$. In addition, differences in daily growth rate and virulence among isolates from different orchards but belonging to the same genotype in the same subpopulation were determined with SAS PROC TTEST by setting orchard as CLASS. Linear regression analysis was conducted with SAS PROC REG to explore the relationship between virulence and daily growth rate.

Characterization of mating system. Bark samples containing apothecia were collected in late December 2004 from a 100-by$100-\mathrm{m}^{2}$ area in a commercial d'Anjou pear orchard (FS orchard) in Peshastin, WA. Samples were obtained from trees in every other row and sampled trees were at least five trees apart within a row. In total, 20 trees were sampled, with one apothecium per tree selected at random for further study. Assuming 1:1 segregation of markers among the progeny from a single fruiting body, random mating, and an even distribution of allele frequencies in a population, eight progeny isolates should provide a $>0.99$ probability of detecting an outcross for each segregating locus $(30,37)$. 
Thus, we chose 10 single-ascospore isolates from each of 20 apothecia to assess segregation of SCAR markers. Production of mycelium and DNA extraction was as described above. Five SCAR markers that were compatible with multiplex PCR were used for this part of the study. SCAR markers were scored as described above. PCR amplifications with IAC primers that did not yield amplicons after modifying template concentration were treated as missing data. The presence of both positive and negative SCAR alleles among the progeny within an apothecium indicated segregation at a given SCAR locus. Segregation of alleles was determined to have occurred at a locus when the observed pattern was not significantly different from a $1: 1$ ratio $(P=0.05)$, determined with a $\chi^{2}$ test (37). Due to the low power of $\chi^{2}$ tests and the small samples of ascospores from each apothecium $(n=$ 10 ), only $9: 1$ or 1:9 segregation ratios were significantly different from $1: 1$ at $P=0.05$ among our ascospore progeny sets

\section{RESULTS}

Population genetic structure. Allele frequencies varied significantly among subpopulations for seven of eight SCAR loci with the nonclone-corrected data set (Table 1). Following clone correction, allele frequencies varied significantly among subpopulations at three of eight SCAR loci. Overall $\theta$ values summed across eight loci were $0.25(P<0.001)$ and $0.13(P<0.001)$ for the nonclone-corrected and clone-corrected data sets, respectively
(Table 1). This indicates that subpopulations of $P$. pyri in the PNW are significantly differentiated, with $\approx 13$ to $25 \%$ of the genetic variation attributed to differences among the five subpopulations (Table 1). Pairwise comparisons of $\theta$ using the nonclone-corrected data set revealed that allele frequencies in all five subpopulations were significantly different at $P<0.01$ (Table 2). In all, 7 of 10 pairwise comparisons of $\theta$ were significant at $P<$ 0.05 using the clone-corrected data set and three genetic clusters were apparent. Allele frequencies were not significantly different among the Omak, Yakima, and Medford subpopulations. The Wenatchee subpopulation was genetically distinct from both Hood River and from Omak, Yakima, and Medford (Table 2). Similarly, phenograms estimated from Nei's genetic distances (data not shown) using both data sets demonstrated that the Omak, Yakima, and Medford subpopulations clustered together and were most closely related to the Hood River subpopulation followed by the Wenatchee subpopulation.

In all, 54 MLGs were identified among 146 isolates, with 24 MLGs occurring at least twice in the overall sample (Table 3). The number of MLGs in four subpopulations was 12 to 15 , while the Hood River subpopulation had 20 MLGs. There were only one or two dominant MLGs (frequencies >20\%) in each subpopulation except Hood River, in which frequencies of all the genotypes were $<20 \%$. The Yakima and Medford subpopulations shared the same dominant MLG, whereas Omak and Wenatchee subpopulations had different dominant MLGs. No MLG was

TABLE 1. Allele frequencies at eight sequence-characterized amplified region (SCAR) loci of Potebniamyces pyri sampled from five subpopulations in the Pacific Northwest before and after clone correction ${ }^{\mathrm{w}}$

\begin{tabular}{|c|c|c|c|c|c|c|c|c|c|}
\hline \multirow[b]{2}{*}{ Subpopulations } & \multicolumn{8}{|c|}{ SCAR loci ${ }^{\mathrm{x}}$} & \multirow[b]{2}{*}{ Overall } \\
\hline & I & II & III & IV & $\mathrm{V}$ & VI & VII & VIII & \\
\hline \multicolumn{10}{|c|}{ Nonclone-corrected data } \\
\hline Omak & 0.345 & 0.414 & 0.103 & 0.103 & 0.624 & 1 & 0.214 & 0.75 & $\ldots$ \\
\hline Hood River & 0.679 & 0.857 & 0.286 & 0.321 & 0.536 & 0.857 & 0.357 & 0.536 & $\ldots$ \\
\hline Yakima & 0.467 & 0.448 & 0.333 & 0.4 & 0.483 & 0.867 & 0.9 & 0.9 & $\ldots$ \\
\hline Medford & 0.815 & 0.333 & 0.148 & 0.037 & 0.111 & 0.889 & 0.222 & 0.37 & $\ldots$ \\
\hline \multicolumn{10}{|c|}{ Clone-corrected data } \\
\hline Omak & 0.286 & 0.429 & 0.143 & 0.214 & 0.5 & 1 & 0.308 & 0.615 & $\ldots$ \\
\hline Wenatchee & 0.308 & 0.615 & 0.077 & 0.846 & 0.75 & 1 & 0.077 & 0.692 & $\ldots$ \\
\hline Hood River & 0.667 & 0.8 & 0.333 & 0.4 & 0.533 & 0.733 & 0.267 & 0.533 & $\ldots$ \\
\hline Yakima & 0.5 & 0.474 & 0.4 & 0.35 & 0.474 & 0.8 & 0.85 & 0.85 & $\ldots$ \\
\hline Medford & 0.667 & 0.5 & 0.167 & 0.083 & 0.083 & 0.833 & 0.167 & 0.417 & $\ldots$ \\
\hline
\end{tabular}

${ }^{w}$ Sample sizes for each subpopulation of nonclone-corrected data: Omak, 29; Wenatchee, 32; Yakima, 28; Hood River, 30; and Medford, 27. Sample sizes for each subpopulation of clone-corrected data: Omak,14; Wenatchee, 13; Yakima, 15; Hood River, 20; and Medford, 12.

${ }^{x}$ Codes of SCAR loci: I = B5-4-1L/NR1; II = B5-4-1L/NR2; III = A11-5-5NL/R; IV = B17-8-1NL1/R; V = B17-8-2NL/R; VI = A11-5-5L/NR; VII = B17-7$1 \mathrm{~L} / \mathrm{NR} ; \mathrm{VIII}=\mathrm{M}-2-5 \mathrm{~L} 3 / \mathrm{NR} 2$.

${ }^{y}$ Likelihood ratio of $\chi^{2}$ tests. Null hypothesis indicates no differences in allele frequencies among subpopulations; ns indicates $P>0.05$; $*$ and $* *$ indicate $P<$ 0.05 and 0.01 , respectively (5).

${ }^{\mathrm{z}}$ Genetic differentiation among subpopulations (56). $\theta$ values estimated using MultiLocus 1.3 (1). Significant level for $\theta$ values: ns indicates $P>0.05$; * indicates $P<0.05 ;$ and $* *$ indicates $P<0.01$.

TABLE 2. Pairwise comparisons of genetic diversity between subpopulations of Potebniamyces pyri in the U.S. Pacific Northwest before and after clone correction $^{2}$

\begin{tabular}{|c|c|c|c|c|c|}
\hline & Omak & Wenatchee & Yakima & Hood River & Medford \\
\hline Omak & & $0.107 *$ & $0.054 \mathrm{~ns}$ & $0.088^{*}$ & $0.062 \mathrm{~ns}$ \\
\hline Wenatchee & $0.308 * *$ & $\ldots$ & $0.097 *$ & $0.225^{*}$ & $0.284 * *$ \\
\hline Yakima & $0.113^{* *}$ & $0.267 * *$ & $\ldots$ & $0.096^{*}$ & $0.058 \mathrm{~ns}$ \\
\hline Medford & $0.199 * *$ & $0.514 * *$ & $0.088^{* *}$ & $0.288^{* *}$ & $\ldots$ \\
\hline
\end{tabular}

${ }^{\mathrm{z}}$ Numbers are $\theta$ values (genetic differentiation among subpopulations) estimated using MultiLocus 1.3 (1). Values below the diagonal line were estimated using nonclone-corrected data sets and values above the diagonal were estimated using clone-corrected data sets. Significant level for $\theta$ values: $\mathrm{ns}$ indicates $P>0.05$; $*$ and $* *$ indicates $P<0.05$ and 0.01 , respectively. 
shared among more than three subpopulations (Table 3). Genotypic diversity was significantly $>0$ in each subpopulation $(0.806$ to 0.966 ).

The distribution of genotypes varied greatly among orchards within the same subpopulation. For example, only four genotypes were observed in the no. 5 orchard in the Omak subpopulation, with three present on the same tree, while six coded genotypes were observed in the no. 6 orchard.

Growth rate, virulence, and their relationship to genotype. No decay developed on inoculated control fruit. Significant differences in virulence on d'Anjou pear fruit and in daily growth rates on $\mathrm{OA}$ at 20 and $0^{\circ} \mathrm{C}$ were detected among isolates with different multilocus SCAR genotypes (Table 4). Isolates of genotype 4 from Omak were the most virulent on d'Anjou pear fruit and had high growth rates on $\mathrm{OA}$ at both temperatures, while isolates of genotype 5 and 6 from Wenatchee were the least virulent and had the slowest growth rates. Significant differences in virulence also were detected among isolates of the same MLG from different orchards within the same subpopulation (data not shown). Isolates with higher virulence levels had higher growth rates on $\mathrm{OA}$ at both temperatures. Regression analysis indicated that virulence was positively and significantly correlated with daily growth rates on $\mathrm{OA}$ at both 20 and $0^{\circ} \mathrm{C}$ (Fig. 2).

Mating system. Various segregation patterns at five SCAR loci were observed among 20 ascospore progeny sets (Table 5). Eighteen apothecia (90\%) had alleles segregating at one or more SCAR loci, indicating that these apothecia were outcrossed. Segregation of alleles was not observed among ascospore progeny sets from two apothecia for all five SCAR loci, possibly indicating that these apothecia were selfed. Segregation patterns of 9:1 or 1:9 were observed in eight apothecia at three loci. Five of these apothecia were confirmed as outcrossed as evidenced by segregation patterns such as 5:5 at one or more additional SCAR loci. In this subpopulation, $\approx 90 \%$ of apothecia were outcrossed, suggesting that the mating system of $P$. pyri is predominantly outcrossing in nature.

\section{DISCUSSION}

Significant genetic differentiation was found among subpopulations of $P$. pyri in the PNW and the mating system of $P$. pyri appears to be predominantly outcrossing. This result suggests that recombination of $P$. pyri may occur in nature and may explain the lack of correlation observed between multilocus SCAR genotype and virulence on pear fruit. The Wenatchee and Hood River subpopulations of $P$. pyri were genetically distinct from the Omak, Yakima, and Medford subpopulations. This differentiation may have resulted from a founder effect (33) combined with earlier

TABLE 4. Virulence of Potebniamyces pyri to d'Anjou pear fruit and daily growth rates of representative isolates of each major sequence-characterized amplified region (SCAR) haplotype ${ }^{\mathrm{w}}$

\begin{tabular}{lllllc}
\hline & \multicolumn{2}{l}{ Lesion diameter $(\mathrm{mm})^{\mathrm{y}}$} & & \multicolumn{2}{c}{ Growth rate $(\mathrm{mm} /$ day $) \mathrm{at}^{\mathrm{z}}$} \\
\cline { 2 - 3 } \cline { 5 - 6 } Haplotype $^{\mathrm{x}}$ & Exp. 1 & Exp. 2 & & $20^{\circ} \mathrm{C}$ & $0{ }^{\circ} \mathrm{C}$ \\
\hline $4(n=6)$ & $90.05 \mathrm{a}$ & $85.91 \mathrm{a}$ & & $4.34 \mathrm{a}$ & $0.93 \mathrm{a}$ \\
$1(n=11)$ & $81.72 \mathrm{~b}$ & $66.62 \mathrm{~b}$ & & $4.21 \mathrm{ab}$ & $0.94 \mathrm{a}$ \\
$12(n=4)$ & $68.93 \mathrm{c}$ & $65.71 \mathrm{~b}$ & & $3.80 \mathrm{bc}$ & $0.96 \mathrm{a}$ \\
$5(n=9)$ & $54.16 \mathrm{~d}$ & $46.66 \mathrm{c}$ & & $3.46 \mathrm{c}$ & $0.88 \mathrm{a}$ \\
$6(n=4)$ & $24.71 \mathrm{e}$ & $44.45 \mathrm{c}$ & & $2.46 \mathrm{~d}$ & $0.71 \mathrm{~b}$ \\
\hline
\end{tabular}

w Values followed by the same letter in the same column were not significantly different based on the Waller-Duncan K-ratio $t$ test at $P=0.05$.

${ }^{x}$ Multilocus SCAR haplotype and number of isolates included in each test in parentheses. Haplotype codes presented in Table 3.

${ }^{y}$ Lesion diameters measured 8 weeks postinoculation in experiment (Exp.) 1 and 2.

${ }^{\mathrm{z}}$ Daily growth rate, means of two experiments.

TABLE 3. Frequency of multilocus sequence-characterized amplified region (SCAR) genotypes in five subpopulations of Potebniamyces pyri in the U.S. Pacific Northwest

\begin{tabular}{|c|c|c|c|c|c|c|}
\hline \multirow[b]{2}{*}{ Code $^{w}$} & \multirow[b]{2}{*}{ Genotype $^{\mathrm{x}}$} & \multicolumn{5}{|c|}{ Subpopulations } \\
\hline & & Omak & Wenatchee & Yakima & Hood River & Medford \\
\hline 1 & 11000100 & 0.069 & $\ldots$ & 0.214 & $\ldots$ & 0.296 \\
\hline 2 & 11001111 & 0.103 & $\ldots$ & $\ldots$ & $\ldots$ & $\ldots$ \\
\hline 4 & 00001101 & 0.241 & 0.031 & $\ldots$ & $\ldots$ & $\ldots$ \\
\hline 5 & 01011111 & $\ldots$ & 0.375 & 0.143 & $\ldots$ & $\ldots$ \\
\hline 6 & 01011101 & $\ldots$ & 0.250 & $\ldots$ & $\cdots$ & $\begin{array}{l}\cdots \\
\cdots\end{array}$ \\
\hline 10 & 11101111 & $\ldots$ & $\ldots$ & 0.107 & 0.067 & 0.111 \\
\hline 11 & 11101100 & $\ldots$ & $\ldots$ & 0.071 & $\ldots$ & $\ldots$ \\
\hline 12 & 00010111 & $\ldots$ & $\ldots$ & $\ldots$ & 0.133 & $\ldots$ \\
\hline 13 & 11011111 & $\ldots$ & $\ldots$ & $\ldots$ & 0.1 & $\ldots$ \\
\hline 14 & 00100111 & $\ldots$ & $\ldots$ & $\ldots$ & 0.067 & $\begin{array}{l}\cdots \\
\cdots\end{array}$ \\
\hline 15 & 10000100 & $\ldots$ & $\ldots$ & $\ldots$ & $\ldots$ & $0.074^{\cdots}$ \\
\hline 21 & 00000100 & 0.069 & $\ldots$ & $\ldots$ & $\ldots$ & 0.074 \\
\hline 22 & 00010100 & 0.034 & 0.031 & 0.036 & $\ldots$ & $\ldots$ \\
\hline 23 & 00000000 & $\ldots$ & $\ldots$ & 0.036 & $\ldots$ & 0.037 \\
\hline 24 & 10000000 & $\ldots$ & $\ldots$ & $\ldots$ & $\ldots$ & 0.074 \\
\hline$\ldots$ & Others & 0.069 & 0.219 & 0.179 & 0.433 & 0.111 \\
\hline$\ldots$ & $n^{\mathrm{y}}$ & 14 & 13 & 15 & 20 & 12 \\
\hline$\ldots$ & Genotypic diversity ${ }^{z}$ & $0.936(P<0.01)$ & $0.806(P=0.013)$ & $0.929(P<0.001)$ & $0.966(P=0.014)$ & $0.892(P=0.011)$ \\
\hline
\end{tabular}

${ }^{\mathrm{w}}$ Only genotype that occurred at least twice in all five subpopulations was assigned a code.

${ }^{x}$ Presence or absence of an allele at a SCAR locus is indicated by 1 and 0 , respectively. The order of SCAR locus within a genotype (from left to right) was the same as in Table 1.

y Total number of multilocus genotypes.

${ }^{\mathrm{z}}$ Probability that two individuals taken at random have different genotypes (1). Values were calculated with program MultiLocus 1.3 and range from 0 to 1. 
establishment of d'Anjou pear orchards in the Wenatchee River and Hood River Valleys compared with the other three subpopulations. All pairwise genetic distances were significant when estimated with the nonclone-corrected data set whereas only 7 of 10 pairwise distances were significant following clone correction. This indicates that repeated sampling of the same MLGs biased the differentiation statistics and overestimated genetic distances among subpopulations, as was observed in a population structure study of Rhynchosporium secalis (26). In a population structure study of the cacao wilt pathogen, Ceratocystis cacaofunesta, clone-corrected data were used for analysis and limited genetic variation was found among recently established populations, similar to the results reported here (11).

In population structure studies of Mycosphaerella graminicola and Magnaporthe grisea, analyses based on clone-corrected and nonclone-corrected data sets yielded similar conclusions regarding genetic distances among subpopulations $(7,21)$. These pathogens have aerially dispersed propagules and isolates were sampled on a small scale. In our study, both conidia and ascospores of $P$. pyri were water dispersed and had limited potential for long-distance dispersal (10), and our sampling scale was much larger than the previous studies described above. These differences in dispersal characteristics and sampling scale may explain the discrepancy we observed between genetic distances estimated among subpopulations with clone-corrected versus nonclonecorrected data.

With the exception of one MLG in relatively high frequency in both the Yakima and Medford subpopulations, no MLGs were shared by more than three subpopulations. Moreover, MLGs that were shared between subpopulations occurred at very low frequencies. These observations suggest that the frequency of current genetic exchange is low among subpopulations and has little impact on the population structure of $P$. pyri in the PNW (33). Because we assume that the movement potential of water-dispersed spores of $P$. pyri is limited, the movement of symptomless plant materials, such as establishment of orchards in one area with plants from nurseries in another area, might be the predominant mechanism of regional movement of this fungus, contributing to gene flow of the pathogen in the region. Thus, using disease-free tree stocks for orchard establishment would limit the spread of the fungus in the region.

We observed diverse MLGs within each subpopulation, which is consistent with recombination in each of the subpopulations (35). The teleomorph has been observed directly in only three of the five subpopulations studied here (60) and, like most other ascomycete fungi, sexual reproduction of $P$. pyri appears to be seasonal (10). We also observed up to three MLGs present on the same tree in an orchard, indicating that genetic variation can be distributed at a fine scale. Such a phenomenon is not unusual among plant-pathogenic fungi. For instance, in the chestnut blight fungus, Cryphonectria parasitica, 33 different genotypes were found in a $25-\mathrm{m}^{2}$ plot (38) and up to six different genotypes were found in a single lesion in the wheat leaf blotch fungus $M y$ cosphaerella graminicola (27).

In the present study, both virulence on fruit and daily growth rate on agar media varied among isolates but we did not find any association between SCAR genotype and virulence on pear fruit. This result is consistent with our observation of a largely outcrossing mating system of $P$. pyri. Associations between molecular genotype and phenotypic traits like growth rate and virulence due to gametic disequilibrium will likely be broken down due to recombination. Our characterization of the mating system confirmed the occurrence of recombination in the population of $P$. pyri, which could explain the lack of correlation between genotypes of the isolates and their virulence on pear fruit. Thus, our results are in support of the hypothesis that recombination in the fungal population eliminates the association between genotype and ecologically important phenotype (36). Such a phenome- non has also been documented in populations of Sclerotinia sclerotiorum (2), Melampsora larici-populina (14), and the rice blast fungus Magnaporthe grisea $(41,43)$.

In this study, we were able to characterize the mating system of the fungus $P$. pyri. Our results suggest that $P$. pyri is likely a heterothallic fungus with a predominantly outcrossing mating system. The mating system of $P$. pyri seems similar to that of the discomycete fungus Crumenulopsis sororia, in which mating occurred exclusively through outcrossing in natural populations (12), and the chestnut blight fungus, Cryphonectria parasitica, which has a mixed mating system, with 74 to $97 \%$ of the perithecia resulting from outcrossing events in various populations around the world $(30,37)$.

Among 20 apothecia examined, segregation at all five SCAR loci was not detected among progeny from two apothecia. We cannot be certain if these two apothecia were selfed or outcrossed because the numbers of loci used for assessing the mating system was relatively small and we did not determine linkage among those loci. In estimating the outcrossing rate of $C$. parasitica, more variable DNA fingerprinting techniques were applied when vic markers did not detect segregation within an ascospore
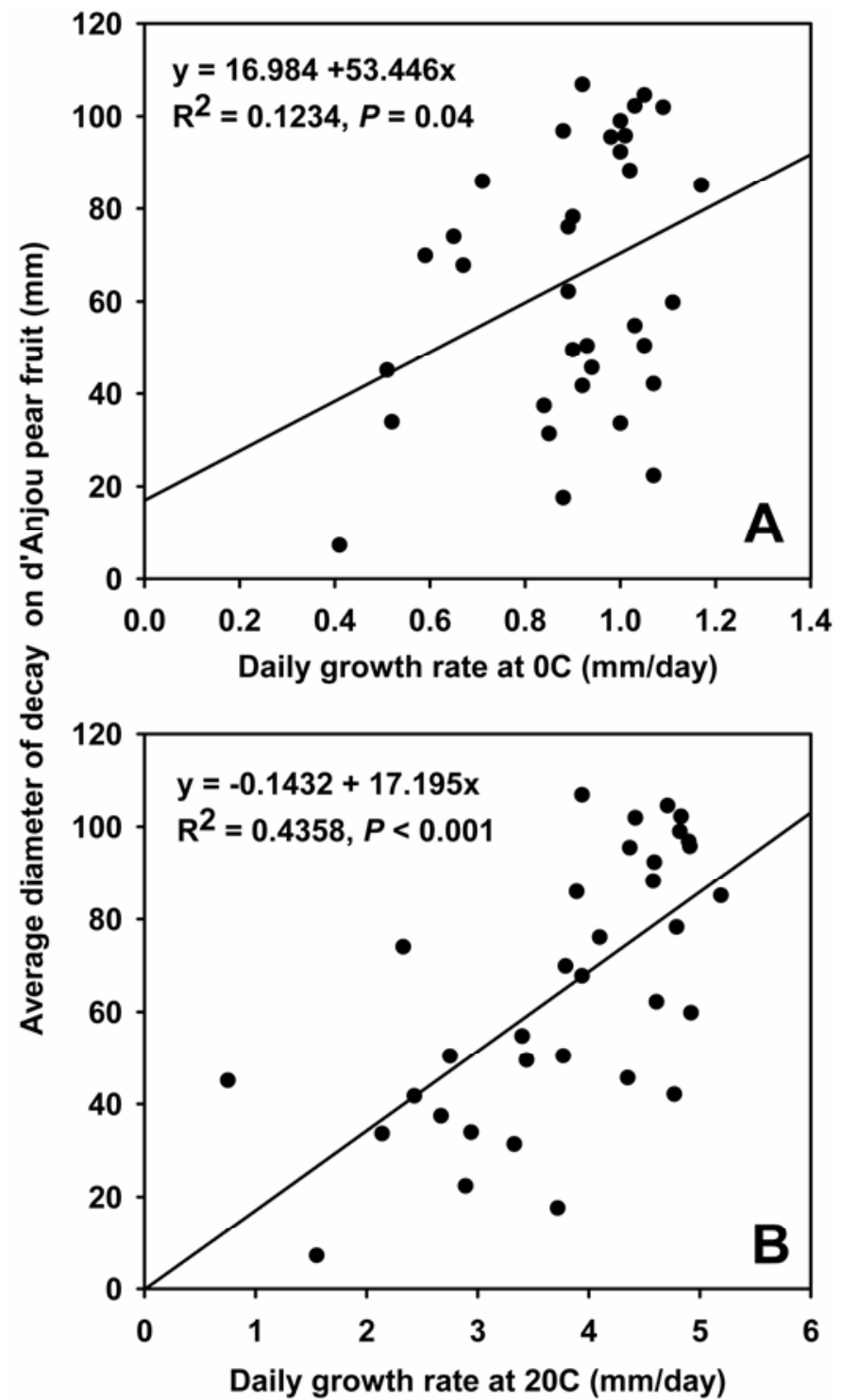

Fig. 2. Relationship between virulence expressed as diameter of lesion on d'Anjou pear fruit and daily growth rate on oatmeal agar at $\mathbf{A}, 0^{\circ} \mathbf{C}$ and $\mathbf{B}$, $20^{\circ} \mathrm{C}$ among isolates of different multilocus sequence-characterized amplified region genotypes. Each data point represents the mean of two independent experiments. 
TABLE 5. Segregation patterns at five sequence-characterized amplified region (SCAR) loci for randomly selected ascospore progeny from 20 apothecia of Potebniamyces pyri collected from a pear orchard in Peshastin, WA

\begin{tabular}{|c|c|c|c|c|c|c|}
\hline \multirow[b]{2}{*}{ Apothecium } & \multicolumn{5}{|c|}{ SCAR locus ${ }^{\mathrm{y}}$} & \multirow[b]{2}{*}{ Segregation $^{\mathrm{z}}$} \\
\hline & B5-4-1 L/NR1 & B5-4-1 L/NR2 & A11-5-5 NL/R & B17-8-1 NL1/R & B17-8-2 NL/R & \\
\hline 1 & $6: 4$ & $10: 0$ & $1: 9 *$ & $10: 0$ & $10: 0$ & + \\
\hline 2 & $0: 10$ & 10:0 & $0: 10$ & $10: 0$ & 10:0 & - \\
\hline 4 & $0: 10$ & $7: 3$ & $0: 10$ & $10: 0$ & $7: 3$ & + \\
\hline 5 & $0: 10$ & 10:0 & $0: 10$ & 10:0 & $9: 1^{*}$ & + \\
\hline 6 & $5: 5$ & $4: 4$ & $7: 3$ & $7: 3$ & 10:0 & + \\
\hline 10 & $0: 10$ & $3: 5$ & $0: 10$ & $5: 5$ & $9: 1 *$ & + \\
\hline 11 & $7: 3$ & $5: 4$ & $0: 10$ & $5: 5$ & $8: 2$ & + \\
\hline 12 & $0: 10$ & $0: 10$ & $0: 10$ & $10: 0$ & $8: 2$ & + \\
\hline 13 & $4: 6$ & $4: 6$ & $0: 10$ & $4: 5$ & $6: 3$ & + \\
\hline 14 & $0: 9$ & $0: 9$ & $0: 10$ & 10:0 & $8: 2$ & + \\
\hline 15 & $6: 4$ & $6: 4$ & $6: 4$ & $7: 3$ & $10: 0$ & + \\
\hline
\end{tabular}

${ }^{y}$ Numbers expressed as presence:absence of amplicon within an ascospore progeny set for each marker. In total, 10 ascospores were tested for most apothecia. If the sum of two numbers in the pattern was less than 10 , there were no amplifications with certain isolates. Patterns marked with "*" deviated significantly $(P=$ 0.05 ) from $1: 1$, indicating that the progeny within this apothecium may have resulted from fertilization by multiple male parents.

${ }^{\mathrm{z}}$ Symbols: + indicates segregation of alleles was observed within an ascospore progeny set at one or more SCAR loci and - indicates no discernable segregation of allele was observed within an ascospore progeny set over all SCAR loci.

progeny set $(30,37)$. Due to small sample sizes, we were unable to determine if more than one male parent was involved in fertilizing a single apothecium. The occurrence of segregation patterns that significantly deviated from a 1:1 ratio was used as evidence that multiple male parents are involved in fertilizing a single fruiting body in Crumenulopsis sororia (12). Our data are very similar to those of Ennos and Swales (12), in which 8 of 25 apothecia were possibly fertilized by multiple male parents; therefore, it is likely that such a phenomenon may also occur in $P$. pyri. This hypothesis could be tested by increasing the number of ascospore progeny sampled per apothecium (12) or using multiallelic genetic markers (37). In order to estimate the outcrossing rate, it is required that all progeny within a single fruiting body are demonstrated to be products of a single fertilization (37). Because we were unable to test the hypothesis of multiple paternal parents, we did not attempt to estimate the outcrossing rate of $P$. pyri.

In summary, we demonstrated the usefulness of SCAR markers for estimating the population structure and characterizing the mating system of the haploid pathogenic fungus, $P$. pyri. We found that the populations of $P$. pyri in the five major pearproduction areas in the U.S. PNW were significantly differentiated and that $P$. pyri predominantly outcrosses in nature. We also found that there was no correlation between genotypes and virulence in causing decay on pear fruit. The information generated in this study should prove valuable for future research on the sexual reproduction and mating system of the fungus.

\section{ACKNOWLEDGMENTS}

This research was supported in part by the Fresh Pear Committee and the Washington State University Agricultural Research Center Graduate Research Assistant Enhancement Program. This manuscript is Plant Pathology New Series 0496, Department of Plant Pathology, College of Agricultural, Human, and Natural Resource Sciences Agricultural Research Center, Project No. WNP00367, Washington State University, Pullman 99164-6430. We thank R. J. Boal, R. A. Spotts, and D. Sugar for assistance with collecting bark samples in pear orchards; H. Akamatsu and M. Chilvers for assistance with SCAR marker development; and R. E. Marra, M. Mazzola, and J. D. Rogers for critical review and valuable suggestions that improved the manuscript.

\section{LITERATURE CITED}

1. Agapow, P. M., and Burt, A. 2001. Indices of multilocus linkage disequilibrium. Mol. Ecol. Notes 1:101-102.

2. Atallah, Z. K., Larget, B., Chen, X., and Johnson, D. A. 2004. High genetic diversity, phenotypic uniformity, and evidence of outcrossing in Sclerotinia sclerotiorum in the Columbia Basin of Washington State. Phytopathology 94:737-742.

3. Barthelet, J. 1943. Recherches sur quelques parasites des arbres fruitiers. Ann. Epiphyties 9:27-45.

4. Brooks, F. T. 1928. On the occurrence of Phacidiella discolor (Mout. \& Sacc.) Potebnia in England. Trans. Br. Mycol. Soc. 13:75-81.

5. Brown, J. K. M. 1996. The choice of molecular marker methods for population genetic studies of plant pathogens. New Phytol. 133:183-195.

6. Chen, Q. H., Wang, Y. C., and Zheng, X. B. 2006. Genetic diversity of Magnaporthe grisea in China as revealed by DNA fingerprint haplotypes and pathotypes. J. Phytopathol. 154:361-369.

7. Chen, R. S., and McDonald, B. A. 1996. Sexual reproduction plays a major role in the genetic structure of populations of the fungus Mycosphaerella graminicola. Genetics 142:1119-1127.

8. Davis, J. E., Kubisiak, T. L., and Milgroom, M. G. 2005. Polymorphic sequence-characterized codominant loci in the chestnut blight fungus, Cryphonectria parasitica. Mol. Ecol. Notes 5:195-197.

9. Deng, Z., Huang, S., Xiao, S., and Gmitter, F. G., Jr. 1997. Development and characterization of SCAR markers linked to the citrus tristeza virus resistance gene from Poncirus trifoliate. Genome 40:697-704.

10. DiCosmo, F., Nag Rag, T. R., and Kendrick, W. B. 1984. A revision of the Phacidiaceae and related anamorphs. Mycotaxon 21:1-234.

11. Engelbrecht, C. J. B., Harrington, T. C., Alfenas, A. C., and Suarez, C. 2007. Genetic variation in populations of the cacao wilt pathogen, Ceratocystis cacaofunesta. Plant Pathol. 56:923-933.

12. Ennos, R. A., and Swales, K. W. 1987. Estimation of the mating system in a fungal pathogen Crumenulopsis sororia (Karst.) groves using isozyme markers. Heredity 59:423-430.

13. Ficke, W., and Peter, E. 1982. Occurrence of apple bark necrosis pathogens so far not identified in the German Rep. Dem. Arch. Phytopathol. U. Pflanzenschutz 18:31-38.

14. Gérard, P. R., Husson, C., Pinon, J., and Frey, P. 2006. Comparison of genetic and virulence diversity of Melampsora larci-populina populations on wild and cultivated poplar and influence of the alternate host. Phytopathology 96:1027-1036.

15. Goodwin, S. B., Sujkowski, L. S., and Fry, W. E. 1996. Widespread distribution and probable origin of resistance to metalaxyl in clonal genotypes of Phytophthora infestans in the United States and Western Canada. Phytopathology 86:793-800.

16. Grünwald, N. J., Goodwin, S. B., Milgroom, M. G., and Fry, W. E. 2003. Analysis of genotypic diversity data for populations of microorganisms. 
Phytopathology 93:738-746.

17. Grünwald, N. J., Sturbaum, A. K., Romero Montes, G., Serrano, E. G., Lozoya-Saldana, H., and Fry, W. E. 2006. Selection for fungicide resistance within a growing season in field populations of Phytophthora infestans at the center of origin. Phytopathology 96:1397-1403.

18. Hoorfar, J., Cook, N., Malorny, B., Wagner, M., Medici, D. D., Abdulmawjood, A., and Fach, P. 2003. Making internal amplification control mandatory for diagnostic PCR. J. Clin. Microbiol. 41:5835.

19. Ioos, R., Husson, C., Andrieux, A., and Frey, P. 2005. SCAR-based PCR primers to detect the hybrid pathogen Phytophthora alni and its subspecies causing alder disease in Europe. Eur. J. Plant Pathol. 112:323335.

20. Kauserud, H., and Schumacher, T. 2001. Outcrossing or inbreeding: DNA markers provide evidence for type of reproductive mode in Phellinus nigrolimitatus (Basidiomycota). Mycol. Res. 105:676-683.

21. Kumar, J., Nelson, R. J., and Zeigler, R. S. 1999. Population structure and dynamics of Magnaporthe grisea in the Indian Himalayas. Genetics 152:971-984

22. Kupferman, E. A. 1998. Postharvest applied chemicals to pears: A survey of pear packers in Washington, Oregon, and California. Tree Fruit Postharvest J. 9:3-24.

23. Kwok, S., Kellogg, D. E., McKinney, N., Spasic, D., Goda, L., Levenson, C., and Sninsky, J. J. 1990. Effects of primer-template mismatches on the polymerase chain reaction: Human immunodeficiency virus type 1 model studies. Nucleic Acids Res. 18:999-1005.

24. Larsen, R. C., Hollingsworth, C. R., Vandemark, G. J., Gritsenko, M. A., and Gray, F. A. 2002. A rapid method using PCR-based SCAR markers for the detection and identification of Phoma sclerotioides: The cause of brown root rot disease of alfalfa. Plant Dis. 86:928-932.

25. Lee, S. B., and Taylor, J. W. 1990. Isolation of DNA from fungal mycelia and single spores. Pages 282-287 in: PCR Protocols: A Guide to Methods and Applications. M. A. Innis, D. H. Gelfand, J. J. Sninsky, and T. J White, eds. Academic Press, San Diego, CA.

26. Linde, C. C., Zala, M., Ceccarelli, S., and McDonald, B. A. 2003. Further evidence for sexual reproduction in Rhynchosporium secalis based on distribution and frequency of mating type alleles. Fungal Genet. Biol. 40:115-125.

27. Linde, C. C., Zhan, J., and McDonald, B. A. 2002. Population structure of Mycosphaerella graminicola: From lesion to continents. Phytopathology 92:946-955.

28. Liu, Q., and Xiao, C. L. 2005. Influence of nutrient and environmental factors on conidial germination of Potebniamyces pyri. Phytopathology 95:572-580.

29. Ma, Z., and Michailides, T. J. 2002. Characterization of Botryosphaeria dothidea isolates collected from pistachio and other plant hosts in California. Phytopathology 92:519-526.

30. Marra, R. E., Cortesi, P., Bissegger, M., and Milgroom, M. G. 2004. Mixed mating in natural populations of the chestnut blight fungus, Cryphonectria parasitica. Heredity 93:189-195.

31. McDermott, J. M., Brändle, U., Dutly, F., Haemmerli, U. A., Keller, S., Müller, K. E., and Wolf, M. S. 1994. Genetic variation in powdery mildew of barley: Development of RAPD, SCAR, and VNTR markers. Phytopathology 84:1316-1321.

32. McDonald, B. A. 1997. The population genetics of fungi: Tools and techniques. Phytopathology 87:448-453.

33. McDonald, B. A. 2004. Population genetics of plant pathogen. The Plant Health Instructor. DOI: 10.1094/PHI-A-2004-0524-01

34. McDonald, B. A., and McDermott, J. M. 1993. Population genetics of plant pathogenic fungi. BioScience 43:311-319.

35. Milgroom, M. G. 1996. Recombination and the multilocus structure of fungal populations. Annu. Rev. Phytopathol. 34:457-477.

36. Milgroom, M. G., and Fry, W. E. 1997. Contributions of population genetics to plant disease epidemiology and management. Adv. Bot. Res. 24:1-30.

37. Milgroom, M. G., Lipari, S. E., Ennos, R. A., and Liu, Y. C. 1993. Estimation of the outcrossing rate in the chestnut blight fungus, Cryphonectria parasitica. Heredity 70:385-392.

38. Milgroom, M. G., Lipari, S. E., and Powell, W. A. 1992. DNA fingerprinting and analysis of population structure in the chestnut blight fungus, Cryphonectria parasitica. Genetics 131:297-306.

39. Milgroom, M. G., and Peever, T. L. 2003. Population biology of plant pathogens. Plant Dis. 87:608-617.

40. Nei, M. 1972. Genetic distance between populations. Am. Nat. 106:283292.

41. Noguchi, M. T., Yasuda, N., and Fujita, Y. 2006. Evidence of genetic exchange by parasexual recombination and genetic analysis of pathogenicity and mating type of parasexual recombinants in rice blast fungus, Magnaporthe oryzae. Phytopathology 96:746-750.

42. Paran, I., and Michelmore, R. W. 1993. Development of reliable PCRbased markers linked to downy mildew resistance genes in lettuce. Theor. Appl. Genet. 85:985-993.

43. Park, S. Y., Milgroom, M. G., Han, S. S., Kang S., and Lee, Y. H. 2003. Diversity of pathotypes and DNA fingerprint haplotypes in populations of Magnaporthe grisea in Korea over two decades. Phytopathology 93:13781385.

44. Peever, T. L., Ibanez, A., Akimitsu, K., and Timmer, L. W. 2002. Worldwide phylogeography of the citrus brown spot pathogen, Alternaria alternata. Phytopathology 92:794-802.

45. Peever, T. L., Su, G., Carpenter-Boggs, L., and Timmer, L. W. 2004 Molecular systematics of citrus-associated Alternaria species. Mycologia 96:119-134.

46. Potebnia, A. 1912. Ein neuer Krebserreger des Apfelbaumes Phacidiella discolor (Mout. Et Sacc.) A. Pot., seine Morrphologie und Entwickelungs-geschichte. Z. Pflanzenkrankh. 22:129-153.

47. Radišek, S., Jakše, J., and Javornik, B. 2004. Development of pathotypespecific SCAR markers for detection of Verticillium albo-atrum isolates from hop. Plant Dis. 88:1115-1122.

48. Rieseberg, L. H. 1996. Homology among RAPD fragments in interspecific comparisons. Mol. Ecol. 5:99-105.

49. Sharma, R. L. 1991. Prevalence of storage rots of China pear in Himachal Pradesh. Plant Dis. Res. 5:109-111.

50. Shieh, M. T., Brown, R. L., Whitehead, M. P., Cary, J. W., Cotty, P. J., Cleveland, T. E., and Dean, R. A. 1997. Molecular genetic evidence for the involvement of a specific polygalacturonase, $\mathrm{P} 2 \mathrm{c}$, in the invasion and spread of Aspergillus flavus in cotton bolls. Appl. Environ. Microbiol. 63:3548-3552.

51. Simsek, M., and Adnan, H. 2000. Effect of single mismatches at 3'-end of primers on polymerase chain reaction. Sultan Qaboos University Medical Science 2:11-14.

52. Snowdon, A. L. 1992. Post-Harvest Disease and Disorders of Fruits and Vegetables. Vol. 1. General Introduction and Fruits. CRC Press, Boca Raton, FL.

53. Soubabere, O., Jorge, V., Notteghem, J. L., Lebrun, M., and Tharreau, D. 2001. Sequence characterized amplified region markers for the rice blast fungus, Magnaporthe grisea. Mol. Ecol. Notes 1:19-21.

54. Southee, E. A., and Brooks, F. T. 1926. Notes on a pycnidial fungus associated with a dying-back of apple branches. Trans. Br. Mycol. Soc. 11:213-219.

55. Thompson, J. D., Gibson, T. J., Plewniak, F., Jeanmougin, F., and Higgins, D. G. 1997. The Clustal X windows interface: Flexible strategies for multiple sequences alignment aided by quality analysis tools. Nucleic Acids Res. 24:4876-4882.

56. Weir, B. S., and Cockerham, C. C. 1984. Estimating F-statistics for the analysis of population structure. Evolution 38:1358-1370.

57. Xiao, C. L., and Boal R. J. 2002. Pathogenicity and infection courts of Phacidiopycnis piri in pears. (Abstr.) Phytopathology 92:S88.

58. Xiao, C. L., and Boal, R. J. 2004. Inoculum availability and seasonal survival of Potebniamyces pyri in pear orchards. (Abstr.) Phytopathology 94:S112.

59. Xiao, C. L., and Boal, R. J. 2004. Prevalence and incidence of Phacidiopycnis rot in d'Anjou pears in Washington State. Plant Dis. 88:413-418

60. Xiao, C. L., and Boal, R. J. 2005. Distribution of Potebniamyces pyri in the U.S. Pacific Northwest and its association with a canker and twig dieback disease of pear trees. Plant Dis. 89:920-925.

61. Xiao, C. L., and Sitton, J. W. 2004. Effects of culture media and environmental factors on mycelial growth and pycnidial production of Potebniamyces pyri. Mycol. Res. 108:926-932. 